\title{
Biocatalytic Conversion Efficiency of Steapsin Lipase Immobilized on Hierarchically Porous Biomorphic Aerogel Supports
}

\author{
Vazhayal Linsha $^{\dagger}$, Kalimadathil Aboo Shuhailath ${ }^{\dagger \dagger}$, Kallyadan Veettil Mahesh ${ }^{\dagger}$, Abdul \\ Azeez Peer Mohamed ${ }^{\dagger}$, Solaiappan Ananthakumar ${ }^{\dagger *}$ \\ ${ }^{\dagger}$ Functional Materials Section, Materials Science and Technology Division (MSTD), \\ Council of Scientific and Industrial Research-National Institute for Interdisciplinary \\ Science and Technology (CSIR-NIIST), Thiruvananthapuram-695019, Kerala, India \\ ${ }^{\ddagger}$ Academy of Scientific and Innovative Research (AcSIR), Council of Scientific and \\ Industrial Research, New Delhi, India
}

*Corresponding author. Tel.: 91-471-2515289, +91-9497271547

E-mail address: ananthakumar70@gmail.com (S. Ananthakumar) 


\section{Content}

1. Experimental Section

Page No.

S1. Preparation of alumino-siloxane (ALS) gel .....................................................S3

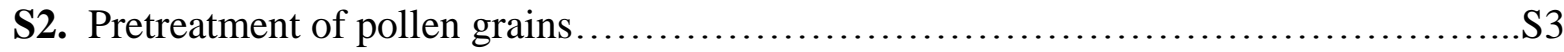

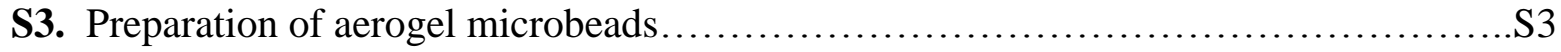

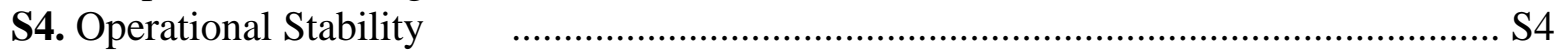

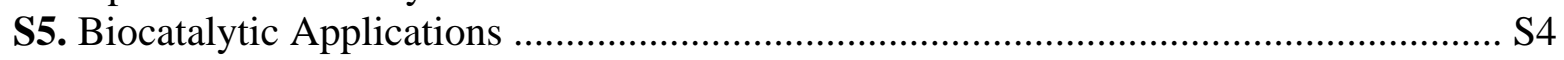

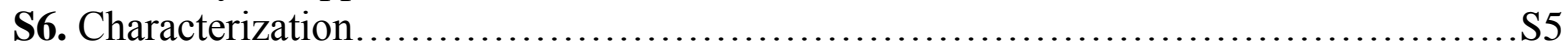

2. Additional Scheme

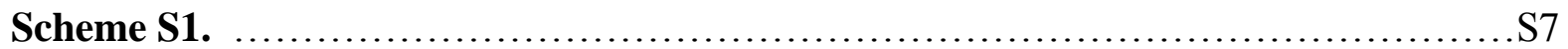

\section{$\underline{\text { 3. Additional Figures }}$}

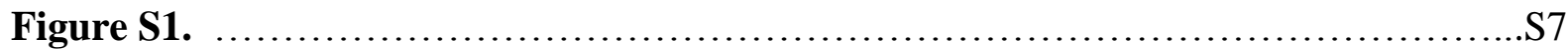

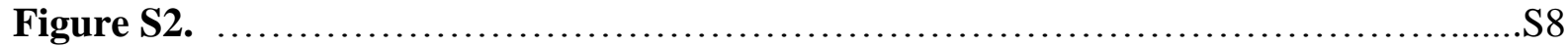

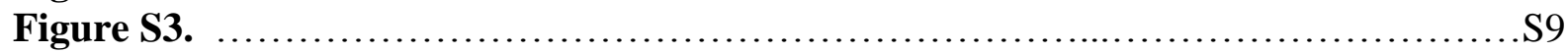

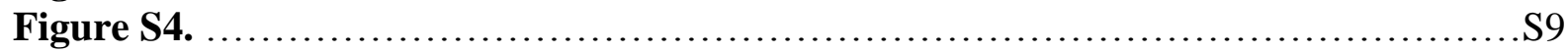

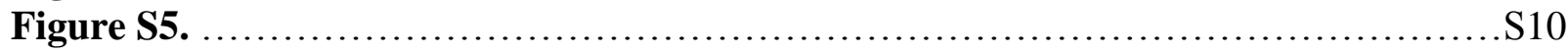

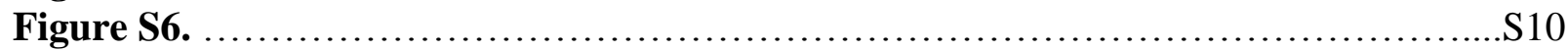

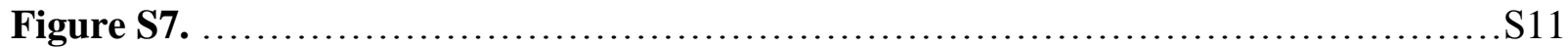

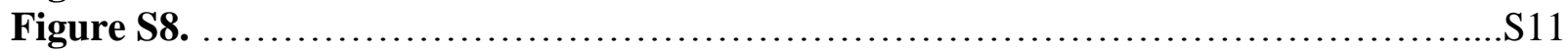

\section{Additional Tables}

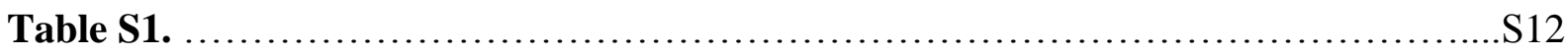

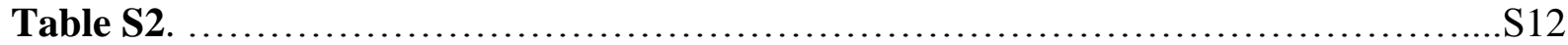

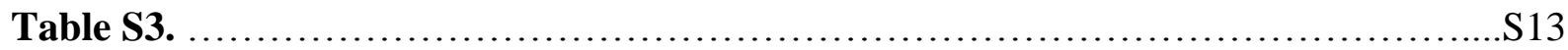

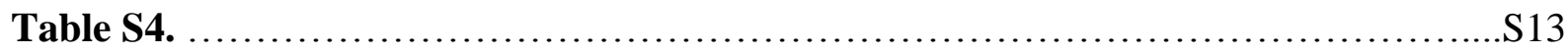

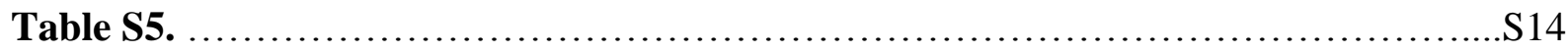

5. Supporting Information References ........................................... 15 


\section{Experimental Section}

\section{S1. Preparation of alumino-siloxane (ALS) gel}

$1 \mathrm{M}$ AIP sol was prepared by hydrolyzing AIP in distilled water for $1 \mathrm{~h}$ at $80{ }^{\circ} \mathrm{C}$. It was further stabilized at pH 3 through peptization using dilute $\mathrm{HNO}_{3}$ with $\mathrm{H}^{+} / \mathrm{Al}^{3+} 0.07$. The peptized AIP sol was then refluxed at $80-85{ }^{\circ} \mathrm{C}$ for $48 \mathrm{~h}$ to remove the generated alcohol and obtained a transparent suspension of alumina nanoparticles. The Al content was gravimetrically estimated to be $0.0725 \mathrm{~g} \mathrm{~mL}^{-1}$ of AIP sol. $2 \mathrm{~g}$ APTMS was then added into $56 \mathrm{~mL}$ of AIP sol to obtain hybrid alumino-siloxane (ALS) gel with $\mathrm{pH}>7$. A secondary introduction of $\mathrm{HNO}_{3}$ at a regulated $\mathrm{pH} 3$ increases the surface potential of the gel and produce clear transparent sol. Upon aging at room temperature, the sol became a flowable gel.

\section{S2. Pretreatment of pollen grains (PG)}

In order to clean impurities on the exine and remove the core substances from the filament, the Hibiscus rosa-sinensis pollen grains need to be pretreated before use. The pretreatment process of the freshly collected pollen grains can be divided into the following three steps.

(1) To remove core substances from the filament and to clean the surface of the pollen grains, the collected samples were shaken by immersed it into $50 \mathrm{~mL}$ ethanol for $5 \mathrm{~h}$. As a result, the pollen grains get detached out from the filament. Then the pollen grains were collected and washed with deionized water several times. The impurities on the surface of the pollen were completely removed through this process. (2) In order to replicate the morphology of the pollen grains, the pollen grains were added into a $20 \mathrm{~mL}$ mixed solution of 1:1 volume ratio ethanol: formaldehyde and shaken for $5 \mathrm{~min}$. Formaldehyde solution is one of the well known fixative or embalming agent often used for morphological fixation ${ }^{1}$. Then, the fixed pollen grains were filtered and washed with deionized water. (3) Fixed pollen grains were frozen and then dried in a laboratory freeze-drier (Vir Tis Genesis 25L Pilot Lyophilizer).

\section{S3. Preparation of aerogel microbeads}

The experimental setup involving controlled drying by a 'subcritical route' via solvent exchange, and surface modification is followed for the preparation of aerogel microbeads. Initially the wet gel microbeads were washed with water and aged in isopropyl alcohol at $50{ }^{\circ} \mathrm{C}$ for $24 \mathrm{~h}$. After washing, solvent exchange with isopropyl alcohol was followed at least five times within $24 \mathrm{~h}$ so as to remove the liquid from the pores. During the washing process the gels were kept at $50{ }^{\circ} \mathrm{C}$. 
This was followed by aging the gels in 50\% TEOS in hexane for 48 hours at $50{ }^{\circ} \mathrm{C}$ and the final solvent exchange with isopropanol maintaining the gels at $50{ }^{\circ} \mathrm{C}$. Subsequently, the excess TEOS from the surface was removed by washing with isopropyl alcohol. The multiple washing and solvent exchange steps involved here are very important to minimize the thermal stress during drying. In order to completely remove the occluded pore liquid from inside the gel network as well as on the surface, the microspheres were dried at $50{ }^{\circ} \mathrm{C}$ at ambient pressure, which resulted in stable aerogel microbeads.

\section{S4. Operational stability of immobilized steapsin lipase}

S4.1. Thermal stability: The thermal stability of immobilized and free steapsin lipase was determined by the incubation at 45 and $50{ }^{\circ} \mathrm{C}$ in a water bath for the desired time $(0-600 \mathrm{~min})$. After the reaction mixture was cooled to room temperature, its activity was measured under standard conditions $\left(\mathrm{pH} 8,30^{\circ} \mathrm{C}\right)$ as described in the main text.

S4.2. Organic solvent stability: Immobilized steapsin lipase (1 mg) was incubated with $1 \mathrm{ml}$ of solvents at $30{ }^{\circ} \mathrm{C}$ for $1 \mathrm{~h}$. Subsequently, the solvent was removed by filtration. Retained solid microbeads (immobilized steapsin lipase) were washed twice with $1 \mathrm{ml}$ of PBS (20 mM, pH 8). Residual enzyme activity was measured as described in the main text. Immobilized steapsin lipase which was not exposed to the organic solvent, was used as the reference.

S4.3. Mechanical and storage stability: The immobilized and free steapsin lipase were immersed in PBS (20 mM, pH 8.0) at room temperature and shaken vigorously at $500 \mathrm{rpm}$ for 10 days. Then the samples were taken out at various time intervals and the residual activities were measured. The storage stability of immobilized and free steapsin lipase was measured by storing at $35^{\circ} \mathrm{C}$ and calculating the residual activity at various intervals of 30 days.

S4.4. Reusability: The recyclability was studied by determining the activity of immobilized derivatives in subsequent reactions relative to that of the first reaction. After each cycle, the immobilized derivatives were washed with hexane and reintroduced into a fresh reaction medium for another assay run and this procedure was repeated up to ten cycles in the same condition as described above.

\section{S5. Biocatalytic Applications}

(a) Hydrolysis reaction. For hydrolytic reaction, free or immobilized steapsin lipase in ALS-PG, MTMS@ALS-PG and APTMS@ALS-PG with equal activity (10 U) were added into a mixture of $0.21 \mathrm{~g}$ of olive oil and $0.5 \mathrm{~mL}$ of PBS $(20 \mathrm{mM}, \mathrm{pH} 8.0)$. The reaction was carried out at $37{ }^{\circ} \mathrm{C}$ 
for $24 \mathrm{~h}$ under mechanical shaking at $200 \mathrm{rpm}$. After the reaction, the catalysts were separated by filtration. The percent of conversion of free fatty acids (FFA) was estimated by measuring the acid value of the product by titration with $\mathrm{KOH}$ solution $(10 \mathrm{mM})$. The conversion of FFA was calculated by the formula (eq.1):

$$
\% \text { conversion of FFA }=\frac{[\mathrm{ai}-\mathrm{at}]}{\mathrm{ai}} \times 100
$$

where 'ai' is the initial acidity of the mixture and 'at' is the acidity at a ' $t$ ' time.

(a) Esterification reaction. For esterification reaction, free or immobilized steapsin lipase in ALS-PG, MTMS@ALS-PG and APTMS@ALS-PG with equal activity (10 U) were added into the mixture containing $0.2 \mathrm{~g}$ of oleic acid, $0.2 \mathrm{~mL}$ of methanol and $1.5 \mathrm{~mL}$ of hexane. The reaction mixture was then mechanically shaken at $200 \mathrm{rpm} @ 40{ }^{\circ} \mathrm{C}$ for $48 \mathrm{~h}$. After the reactions, the catalysts were separated from the previous reaction mixture by centrifugation or filtration, washed three times with hexane and then the catalysts were reused for another cycle. The conversion of FFA was determined by titration method as described in eq.1. The influence of higher concentration of methanol on reaction rate was analyzed by varying oleic acid: methanol ratio (1:1, 1:2, 1:6, 1:8, 1:10 and 1:20). Similarly, the effect of solvent (hexane) was also studied by catalyzing the reaction in presence and absence of the solvent.

(c)Transesterification reaction. The transesterification reaction was performed in a glass vial containing olive oil $(0.21 \mathrm{~g})$, methanol $(0.175 \mathrm{~g})$, and free or immobilized steapsin lipase equal activity $(10 \mathrm{U})$ and $1.5 \mathrm{~mL}$ of cyclohexane. The reaction mixture was incubated under shaking (200 rpm) at $40{ }^{\circ} \mathrm{C}$ for $12 \mathrm{~h}$. After separating the catalyst from the reaction mixture by centrifugation/filtration, washed three times with cyclohexane, and then the catalysts were reused for another cycle. The amount of product, fatty acid methyl esters (FAMEs, the main components of biodiesel), was analyzed by ${ }^{1} \mathrm{H}$ NMR. The yield of FAMEs (\%) was determined by integrating the ratio of the signals at $2.3 \mathrm{ppm}$ (a-carbon methylene groups of all fatty acid derivatives) and $3.6 \mathrm{ppm}$ (methoxy groups of the fatty acid methyl esters) ${ }^{2-4}$.

\section{S6. Characterization}

Structural analysis of the samples was performed by Fourier Transform Infrared (FTIR) spectrophotometer, IR Prestige-21 Shimadzu in the wavelength range 4000 to $400 \mathrm{~cm}^{-1}$ using $\mathrm{KBr}$ pellet technique in transmittance mode. The thermal decomposition of the prepared samples was investigated by Thermo Gravimetric Analyzer (TGA), TG-50 Shimadzu between the 
temperature range $100-1000{ }^{\circ} \mathrm{C}$ at a constant heat flow of $5{ }^{\circ} \mathrm{C} \mathrm{min}^{-1}$ in air atmosphere. XRD patterns were obtained with a Philips X'pertPro diffractometer in the $2 \theta$ range $10-90^{\circ}$ using $\mathrm{Cu}$ $\mathrm{K} \alpha$ radiation $(\lambda=1.54178 \AA$ ). The surface charge analysis was carried out using $3000 \mathrm{H}$ Malvern Zetasizer Instrument. The microstructures of the samples were examined using Scanning Electron Microscope (SEM) ZEISS EVO 18 Special Edition operated at $20 \mathrm{kV}$. Elemental distribution was determined using Energy Dispersive X-ray Spectroscopy (EDS) analysis coupled with ZEISS EVO 18-SEM. Transmission electron microscope images were recorded using Transmission electron microscope (TEM) FEI Tecnai $30 \mathrm{G}^{2} \mathrm{~S}$ - TWIN operated at an accelerating voltage of $300 \mathrm{kV}$. Nitrogen adsorption/desorption analysis of the samples were preformed with a Micromeritics Gemini 2375 instrument. All the samples were degassed at 200 ${ }^{\circ} \mathrm{C}$ for $2 \mathrm{~h}$ and the functionalized samples were degassed at $100{ }^{\circ} \mathrm{C}$ for $2 \mathrm{~h}$ under nitrogen atmosphere prior to adsorption measurements. The Brunauer Emmett Teller (BET) model was utilized to calculate the specific surface areas. Desorption isotherm was used to determine the pore-size distribution using the Barret-Joyner-Halender (BJH) model. UV/Vis spectrophotometer, UV 240 IPC, Shimadzu was used to analyze the concentration and activity of the enzyme. Liquid-phase ${ }^{1} \mathrm{H}$ NMR analysis was obtained with a Bruker DPX-500 MHz NMR spectrometer with an operating frequency of $500 \mathrm{MHz}$, using tetramethylsilane as internal standard. 


\section{Additional Scheme}

Scheme S1. Schematic illustration of (1) hydrolysis (2) esterification and (3) transesterification reactions catalyzed by immobilized steapsin lipase on porous aerogel supports

\section{Hydrolysis}

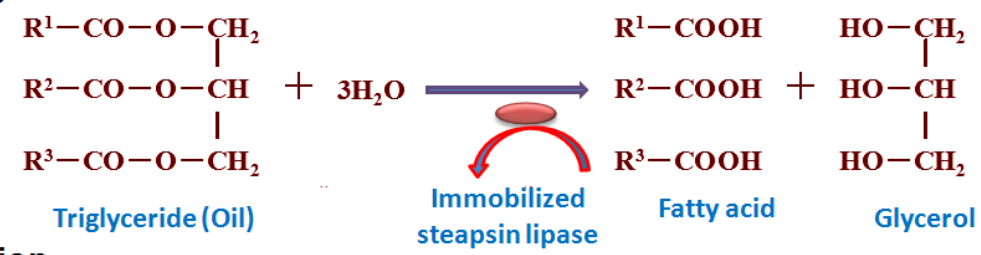

\section{Esterification}

$$
\begin{aligned}
& \text { Immobilized } \quad \text { Fatty acid } \quad \text { Glycerol } \\
& \text { steapsin lipase }
\end{aligned}
$$

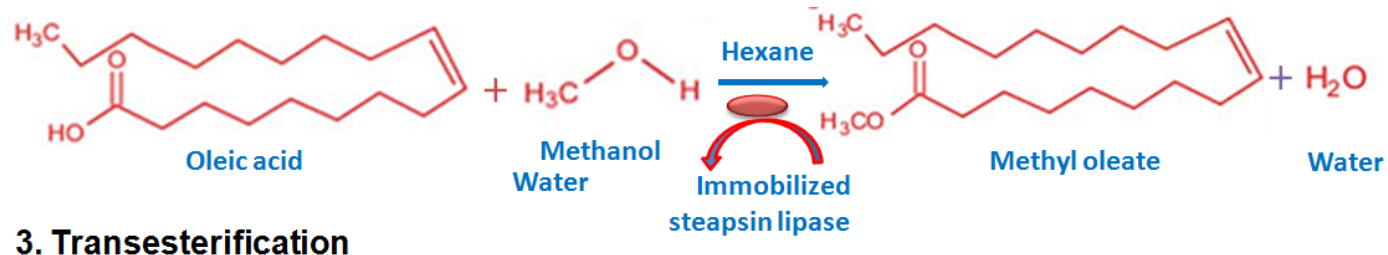

3. Transesterification

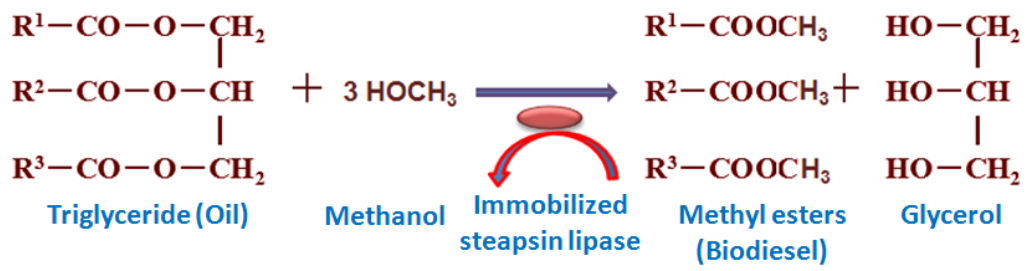

\section{Additional Figures}

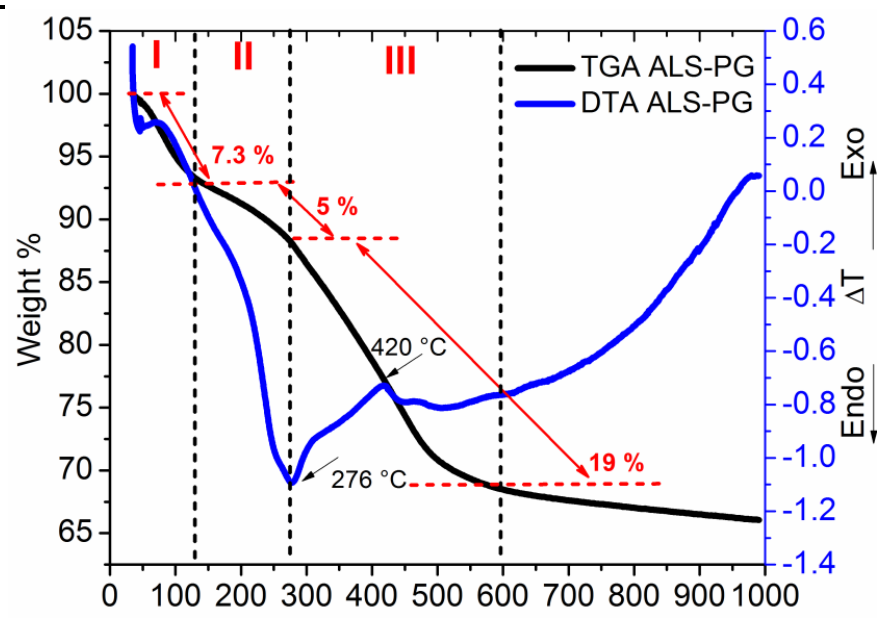

Temperature $\left({ }^{\circ} \mathrm{C}\right)$

Figure S1. TGA/DTA profiles of ALS-PG under $\mathrm{O}_{2}$ flow with a heating rate $5^{\circ} \mathrm{C} \mathrm{min}^{-1}$ 

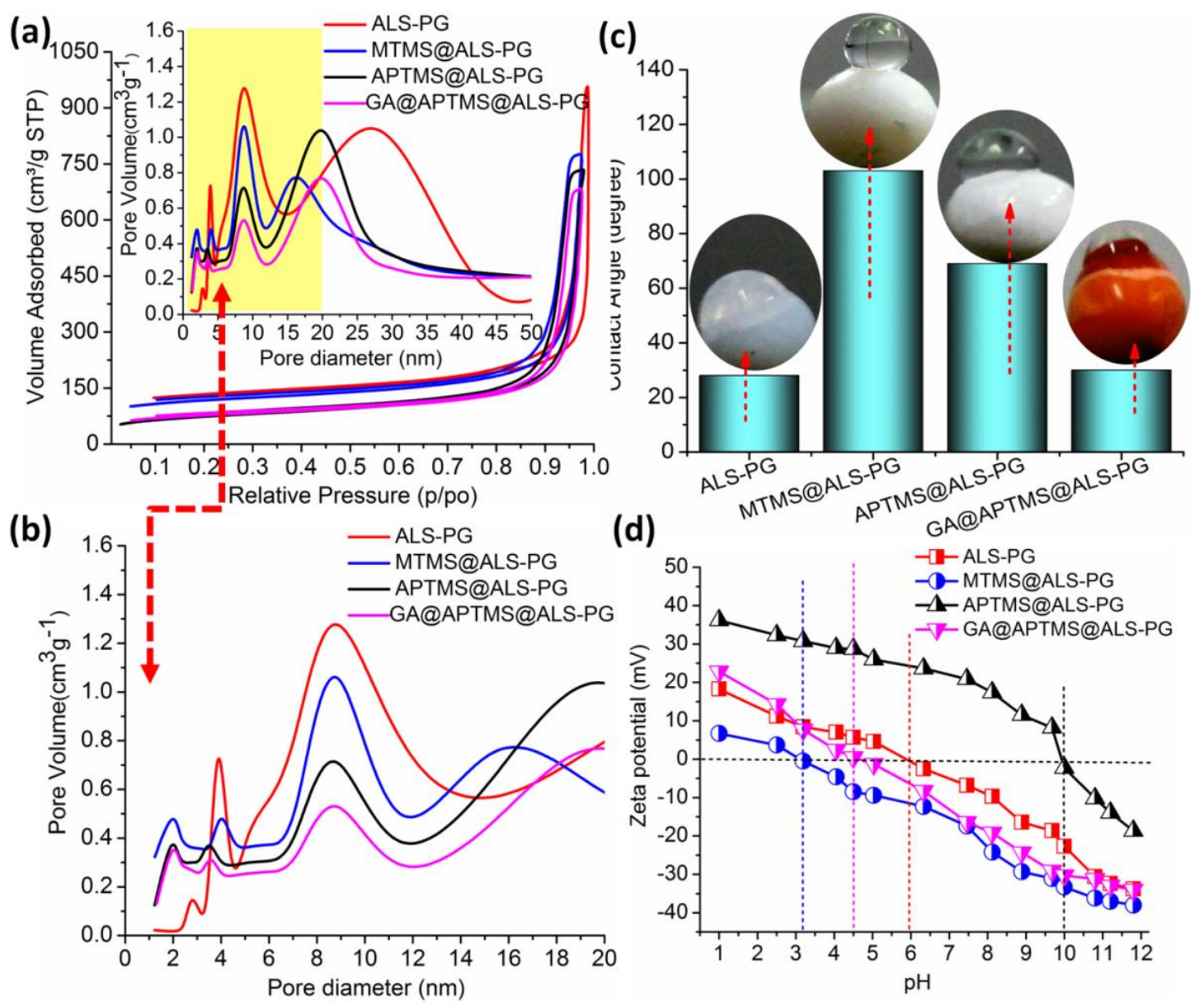

Figure S2. (a) Nitrogen adsorption/desorption analysis corresponding pore size distribution 1-50 $\mathrm{nm}$ (inset) (b) Pore size distribution analysis in the 1-20nm, and (c) powder contact angle and (d) Zeta potential results of ALS-PG and modified ALS-PG aerogel supports. 

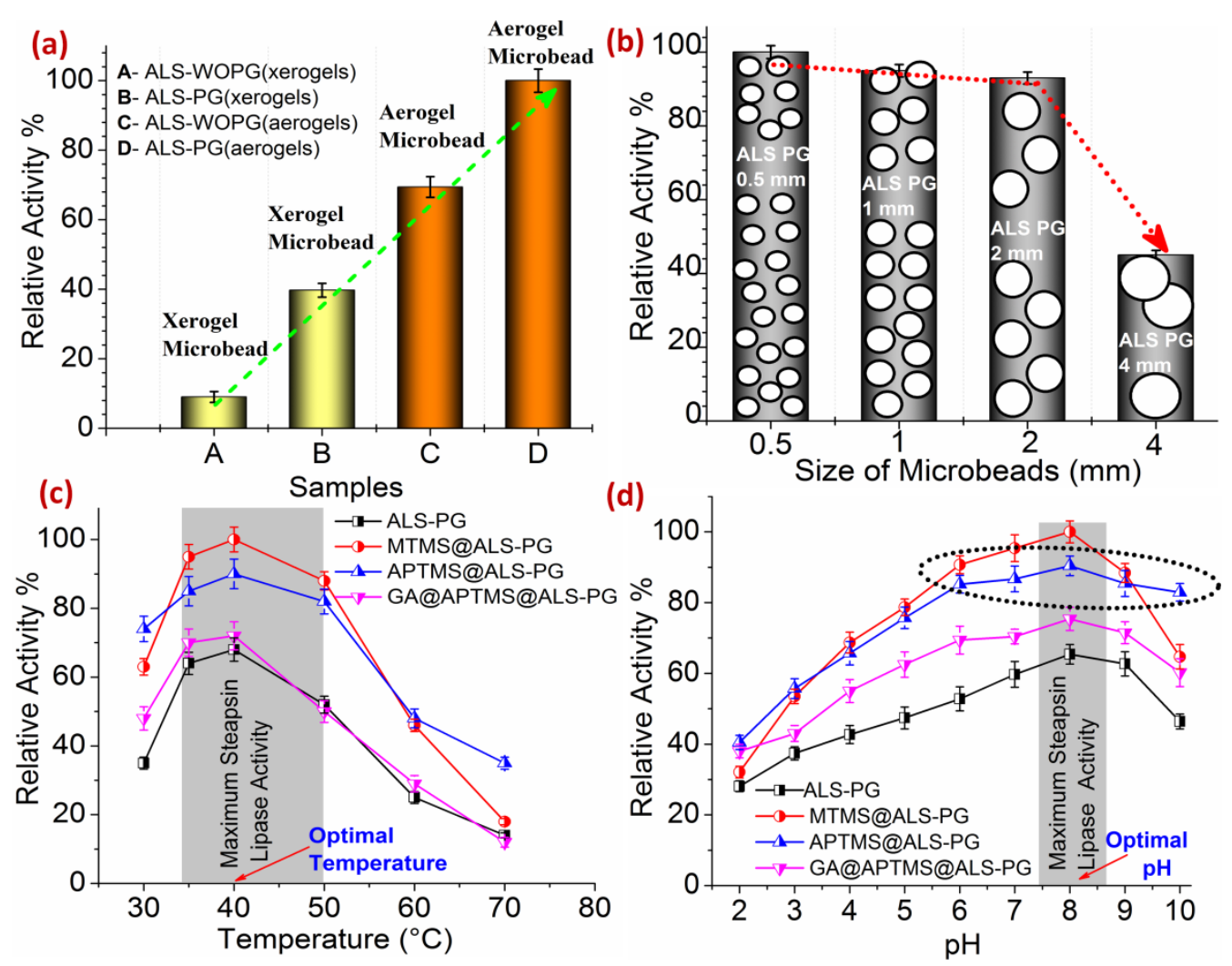

Figure S3. Effects of (a) drying conditions (b) microbead size (a) $\mathrm{pH}$ and (b) temperature on enzymatic activity of immobilized steapsin lipase.

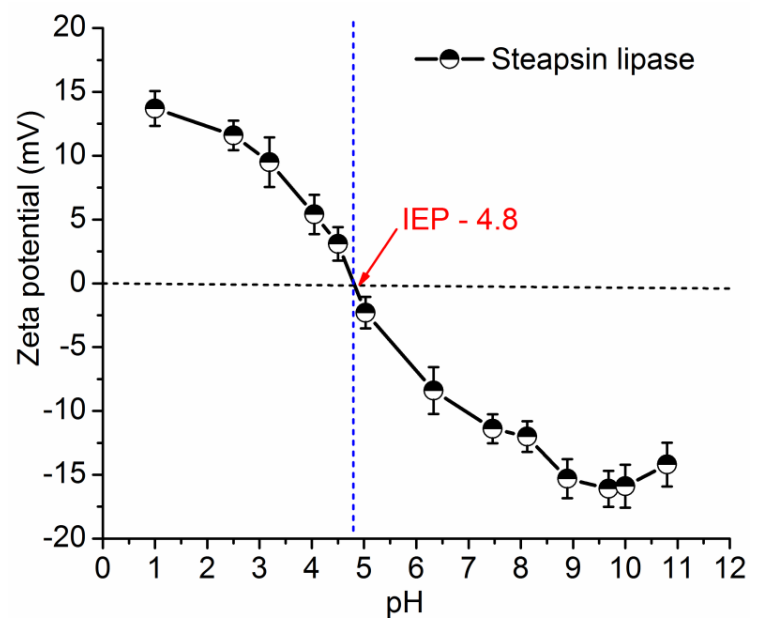

Figure S4. Zeta potential curve of steapsin lipase; error bars show standard deviations for at least three measurements. 

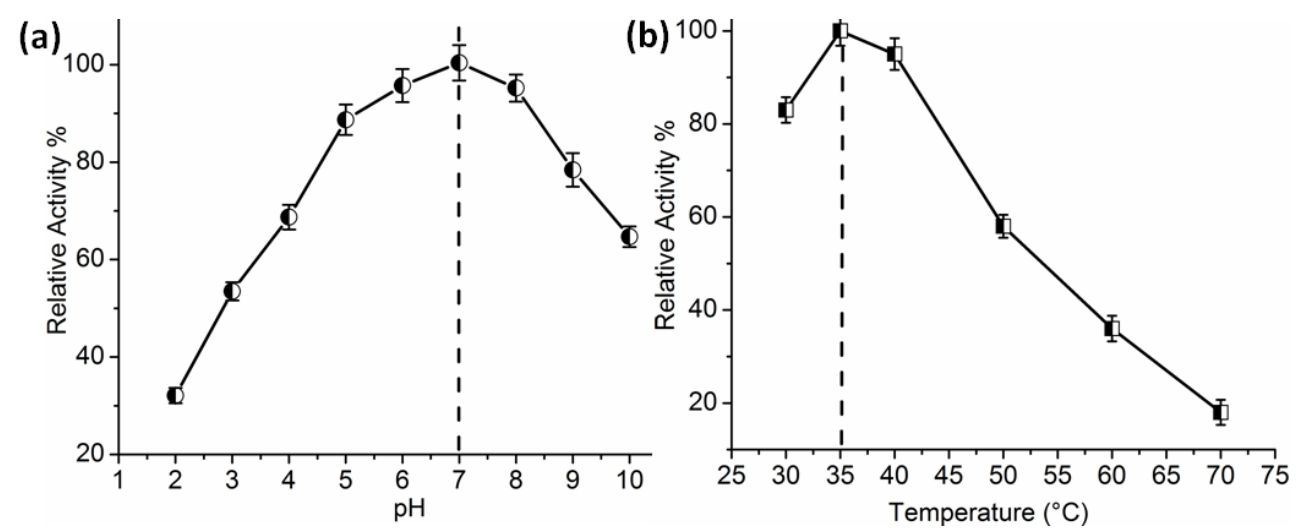

Figure S5. Effect of (a) $\mathrm{pH}$ and (b) temperature on enzymatic activities of the free steapsin lipase

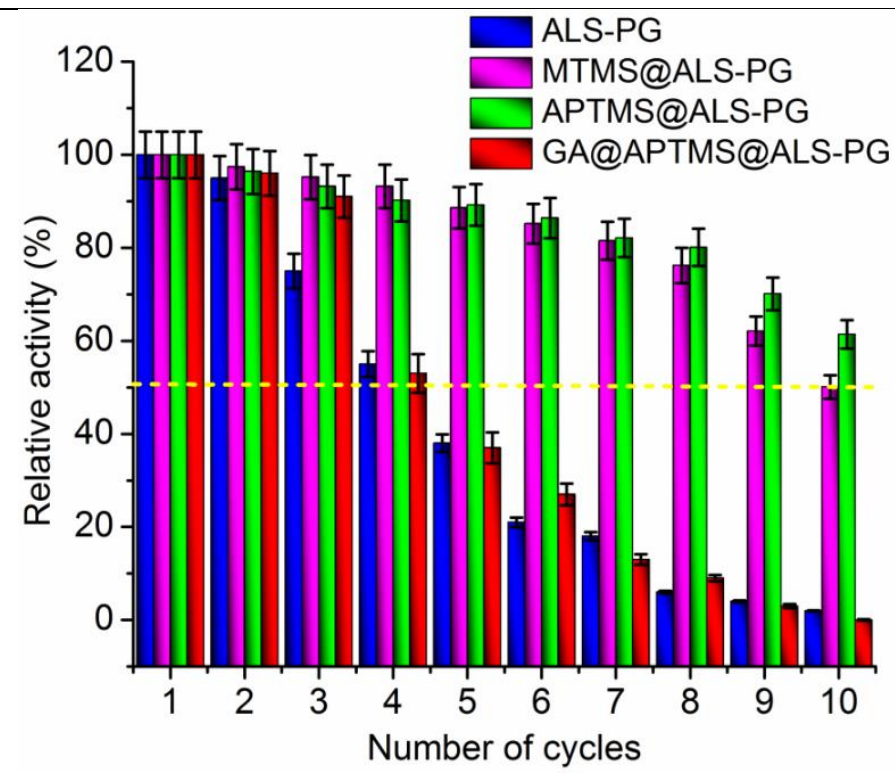

Figure S6. Reusability of the immobilized steapsin lipase 

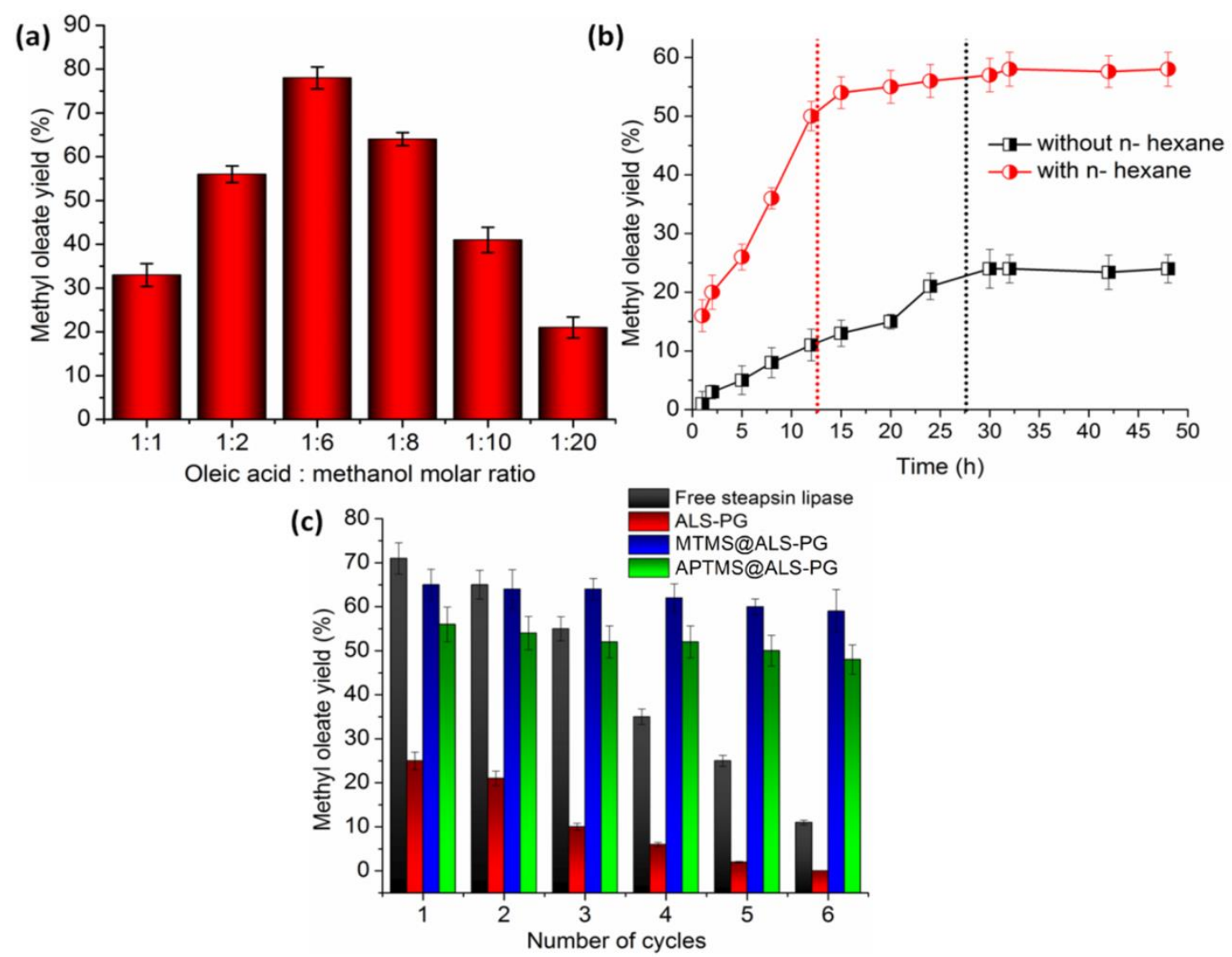

Figure S7. Effect of (a) different molar ratios of oleic acid: methanol on the methyl oleate yield, (b) $n$-hexane as the solvent on the methyl oleate yield, and (c) reusability of the free and immobilized steapsin lipases in esterification reaction of oleic acid.

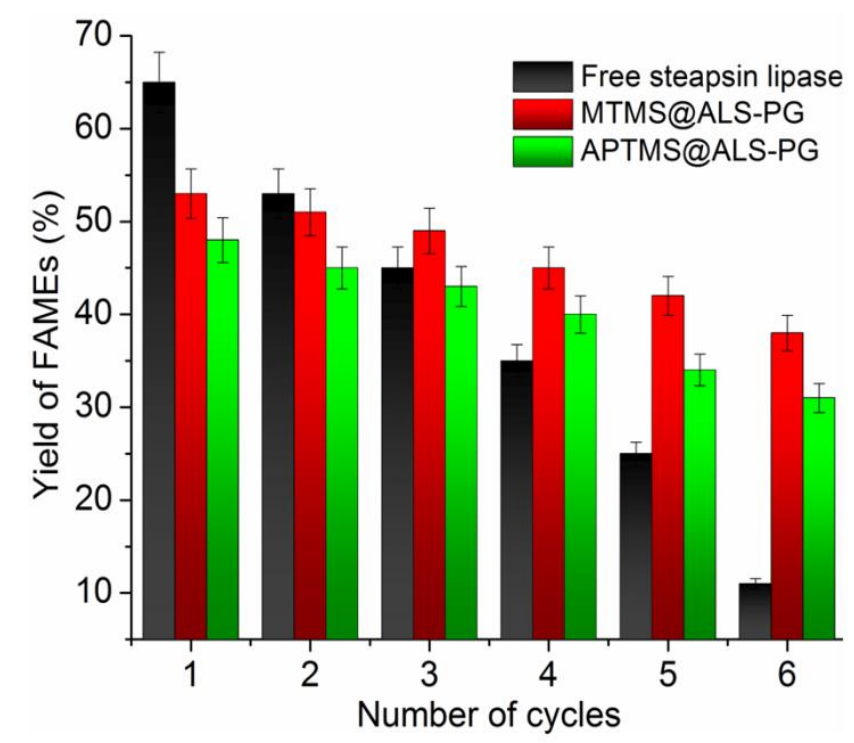

Figure S8. Reusability of the free and immobilized steapsin lipases in transesterification reaction of olive oil 


\section{Additional Tables}

Table S1 Physicochemical properties of porous gel support.

\begin{tabular}{|c|c|c|c|c|c|c|c|}
\hline \multirow[t]{2}{*}{ Sample Name } & \multirow[t]{2}{*}{$\begin{array}{c}\text { a } \\
\text { Shrinkage } \\
(\%)\end{array}$} & \multirow[t]{2}{*}{$\begin{array}{l}\text { Density } \\
\left(\mathrm{g} \mathrm{cm}^{-3}\right)\end{array}$} & \multicolumn{2}{|c|}{$\begin{array}{c}\text { b Surface } \\
\text { area } \\
\left(\mathrm{m}^{2} \mathrm{~g}^{-1}\right)\end{array}$} & \multicolumn{2}{|c|}{$\begin{array}{l}{ }^{\mathbf{c}} \text { Pore diameter } \\
(\mathrm{nm})\end{array}$} & \multirow{2}{*}{$\begin{array}{c}{ }^{\mathbf{d}} \begin{array}{c}\text { Total } \\
\text { pore }\end{array} \\
\text { volume } \\
\left(\mathrm{cm}^{3} \mathrm{~g}^{-1}\right) \\
\mathrm{V}_{\mathrm{p}}\end{array}$} \\
\hline & & & $\mathrm{S}_{\mathrm{BET}}$ & $\mathrm{S}_{\text {Lang }}$ & $\begin{array}{c}\mathrm{D}_{\mathrm{a}} \\
(<20 \mathrm{~nm} \\
)\end{array}$ & $\begin{array}{c}\mathrm{D}_{\mathrm{b}} \\
(<50 \mathrm{~nm})\end{array}$ & \\
\hline ALS-WO-PG (aerogel) & $20 \pm 2$ & 0.291 & 329 & 532 & 5.5 & 12.1 & 1.4156 \\
\hline ALS-PG (aerogel) & $18 \pm 2$ & 0.249 & 497 & 664 & $3.9 / 8.7$ & 26.6 & 1.6788 \\
\hline ALS-WO-PG (xerogel) & $78 \pm 3$ & 0.605 & 192 & 262 & 4.2 & - & 0.7522 \\
\hline ALS-PG (xerogel) & $76 \pm 5$ & 0.613 & 236 & 358 & 6.8 & - & 0.9589 \\
\hline
\end{tabular}

(a)- Shrinkage $=100[$ (diameter of as-prepared samples) - (diameter after drying) $]$, (b)- $\mathrm{S}_{\mathrm{BET}}$ BET (Brunauer-Emmet-Teller) surface areas calculated by BJH model from nitrogen sorption data and $\mathrm{S}_{\text {Lang }}$ - Langmuir surface area, (c)- $\mathrm{D}_{\mathrm{a}}$-The mesopore diameters of the samples. $\mathrm{D}_{\mathrm{b}}$ - The large pore diameter of the samples obtained, (d)- Total pore volumes calculated as the amount of $\mathrm{N}_{2}$ adsorbed at $\mathrm{p} / \mathrm{p}_{0}$ is 0.99 .

Table S2 Textural parameters of functionalized porous aerogel support.

\begin{tabular}{|l|c|c|c|c|c|c|}
\hline \multicolumn{1}{|c|}{ Sample Name } & $\begin{array}{c}\text { a Surface area } \\
\left(\mathrm{m}^{2} \mathrm{~g}^{-1}\right)\end{array}$ & \multicolumn{3}{|c|}{$\begin{array}{c}\text { bore diameter } \\
(\mathrm{nm})\end{array}$} & $\begin{array}{c}\text { c } \\
\text { Total pore } \\
\text { volume } \\
\left(\mathrm{cm}^{3} \mathrm{~g}^{-1}\right)\end{array}$ \\
\cline { 2 - 7 } & $\mathrm{S}_{\mathrm{BET}}$ & $\mathrm{S}_{\text {Lang }}$ & $\begin{array}{c}\mathrm{D}_{\mathrm{a}} \\
(<5 \mathrm{~nm})\end{array}$ & $\begin{array}{c}\mathrm{D}_{\mathrm{b}} \\
(5-15 \mathrm{~nm})\end{array}$ & $\begin{array}{c}\mathrm{D}_{\mathrm{b}} \\
(>50 \mathrm{~nm})\end{array}$ & \\
\hline ALS-PG & 497 & 664 & 2.8 & $3.9 / 8.7$ & 26.6 & 1.6788 \\
\hline MTMS@ ALS-PG & 341 & 543 & 2.1 & $4.0 / 8.7$ & 15.7 & 1.4364 \\
\hline APTMS@ ALS-PG & 298 & 464 & 2.0 & $3.6 / 8.6$ & 19.6 & 1.2245 \\
\hline $\begin{array}{l}\text { GA@APTMS@ ALS- } \\
\text { PG }\end{array}$ & 224 & 401 & 1.9 & $3.4 / 8.5$ & 19.4 & 1.0874 \\
\hline
\end{tabular}

Textural properties are shown for the modified samples of optimized composition having maximum protein immobilization capacity. (a)- $\mathrm{S}_{\mathrm{BET}}$ - BET surface areas calculated by BJH model from nitrogen sorption data and $\mathrm{S}_{\text {Lang }}$ Langmuir surface area, (b) - The mesopore diameters of the samples at various range. (c)- Total pore volumes calculated as the amount of $\mathrm{N}_{2}$ adsorbed at $\mathrm{P} / \mathrm{P} 0$ is 0.99 . 
Table S3: Optimum conditions of steapsin-lipase immobilization on porous aerogel supports

\begin{tabular}{|c|c|c|c|}
\hline $\begin{array}{c}\text { Samples } \\
\text { used for Immobilization }\end{array}$ & $\begin{array}{c}\text { Protein Loading } \\
\text { (Q) } \\
\text { (mg/g support) }^{\mathrm{a}}\end{array}$ & $\begin{array}{c}\text { Immobilization } \\
\text { Yield (IY) } \\
(\%)^{b}\end{array}$ & $\begin{array}{c}\text { Enzyme Activity } \\
\text { (EA) } \\
\text { (U/g support) }\end{array}$ \\
\hline Free steapsin lipase & - & - & 1004.13 \\
\hline ALS-WO-PG (aerogel) & 11.2 & 41.40 & 135.86 \\
\hline ALS-PG (aerogel) & 32.3 & 74.21 & 728.75 \\
\hline ALS-WO-PG (xerogel) & 0.73 & 9.01 & 95.71 \\
\hline ALS-PG(xerogel) & 1.58 & 18.71 & 187.85 \\
\hline \multicolumn{4}{|c|}{ (a) Effect of MTMS modification on ALS/PG } \\
\hline MTMS@ALS-PG-5\% & 41.2 & 82.22 & 854.73 \\
\hline MTMS@ALS-PG-10\% & 53.1 & 91.45 & 928.91 \\
\hline MTMS@ALS-PG-15 \% & 69.8 & 96.87 & 971.72 \\
\hline MTMS@ALS-PG- 25\% & 54.3 & 91.46 & 928.36 \\
\hline \multicolumn{4}{|c|}{ (b) Effect of APTMS modification on ALS/PG } \\
\hline APTMS@ALS-PG-5 \% & 36.2 & 77.94 & 782.56 \\
\hline APTMS@ALS-PG-10\% & 65.1 & 94.96 & 967.26 \\
\hline APTMS@ALS-PG-15\% & 53.8 & 91.62 & 822.45 \\
\hline APTMS@ALS-PG- $20 \%$ & 32.1 & 73.14 & 734.26 \\
\hline \multicolumn{4}{|c|}{ (c) Effect of GA modification on APTMS@ALS/PG } \\
\hline GA@APTMS@ALS/PG-0.5\% & 34.2 & 74.42 & 701.96 \\
\hline GA@APTMS@ALS-PG-1\% & 19.6 & 51.57 & 528.76 \\
\hline GA@APTMS@ALS-PG-1.5\% & 9.60 & 30.14 & 311.56 \\
\hline GA@APTMS@ALS-PG-2\% & 2.40 & 19.16 & 199.74 \\
\hline
\end{tabular}

(a)- Determined by Bradford method, (b)- Activity of immobilized steapsin lipases was carried out via by the hydrolysis of pNPP as described in the experimental section of the manuscript. The activity of free steapsin lipase was given as U/g enzyme, and immobilized steapsin lipase activities were expressed as U/g support

Table S4: Effects of solvents on the stability immobilised steapsin lipase on various porous aerogel supports.

\begin{tabular}{ccccccc}
\hline Organic & Log P & Dipole & \multicolumn{4}{c}{ Relative activity (\%) } \\
\cline { 4 - 7 } solvent & & moment & ALS-PG & MTMS@ALS-PG & APTMS@ ALS-PG & $\begin{array}{c}\text { GA@ } \\
\text { APTMS@ ALS-PG }\end{array}$ \\
\hline Control & - & - & 100 & 100 & 100 & 100 \\
Acetone & -0.23 & 2.88 & $101 \pm 1.2$ & $102 \pm 1.7$ & $101 \pm 4.2$ & $86 \pm 3.7$ \\
Acetonitrile & -0.33 & 3.20 & $84 \pm 1.7$ & $96 \pm 2.0$ & $67 \pm 1.0$ & $73 \pm 2.7$ \\
Ethanol & -0.24 & 1.69 & $76 \pm 2.0$ & $87 \pm 4.7$ & $98 \pm 2.2$ & $66 \pm 2.3$ \\
Isopropanol & 0.28 & 1.66 & $87 \pm 4.7$ & $53 \pm 1.4$ & $93 \pm 3.2$ & $47 \pm 3.7$ \\
Methanol & -0.76 & 1.70 & $63 \pm 1.4$ & $83 \pm 1.5$ & $85 \pm 2.4$ & $56 \pm 1.1$ \\
Butanol & 0.80 & 1.66 & $11 \pm 1.5$ & $21 \pm 0.8$ & $33 \pm 3.4$ & $09 \pm 1.5$ \\
n-Hexane & 3.50 & 0.00 & $98 \pm 3.8$ & $107 \pm 2.1$ & $103 \pm 1.8$ & $83 \pm 0.8$ \\
Toluene & 2.50 & 0.36 & $95 \pm 2.1$ & $108 \pm 5.2$ & $108 \pm 3.1$ & $84 \pm 2.1$ \\
\hline
\end{tabular}


Table S5. Comparative analysis of various standard supports with hierarchically porous aerogel supports for protein loading, yield of immobilization and enzymatic activity.

\begin{tabular}{|c|c|c|c|c|c|c|c|}
\hline $\begin{array}{c}\text { Support } \\
\text { used for } \\
\text { immobilizati } \\
\text { on }\end{array}$ & Types of pore & $\begin{array}{l}\text { Surface } \\
\text { area } \\
\left(\mathrm{m}^{2} \mathrm{~g}^{-1}\right)\end{array}$ & $\begin{array}{l}\text { Pore diameter } \\
\quad(\mathrm{nm})\end{array}$ & $\begin{array}{c}\text { Surface } \\
\text { properties }\end{array}$ & $\begin{array}{l}\text { Protein } \\
\text { Loading } \\
\text { (mg g }^{-1} \\
\text { support) }\end{array}$ & $\begin{array}{c}\text { Immobiliz } \\
\text { ation yield } \\
(\%)\end{array}$ & $\begin{array}{c}\text { Enzyme } \\
\text { activity } \\
\left(\mathrm{U} \mathrm{g}^{-1}\right. \\
\text { support }) \\
\end{array}$ \\
\hline Zeolites & $\begin{array}{l}\text { Microporous } \\
\text { (ordered) }\end{array}$ & 277 & $\begin{array}{c}0.5 \\
\text { (Uni-modal } \\
\text { pore) }\end{array}$ & $\begin{array}{l}\text { Positively } \\
\text { charged } \\
\text { surface }\end{array}$ & 1.23 & 17.42 & 187.12 \\
\hline MCM-41 & $\begin{array}{l}\text { Mesoporous } \\
\text { (Ordered) }\end{array}$ & 895 & $\begin{array}{c}2.8 \\
\text { (Uni-modal } \\
\text { pore) }\end{array}$ & $\begin{array}{l}\text { Hydrophilic } \\
\text { surface }\end{array}$ & 21.6 & 55.8 & 513.79 \\
\hline $\begin{array}{l}\text { Alumina } \\
\left(\mathrm{Al}_{2} \mathrm{O}_{3}\right)\end{array}$ & $\begin{array}{l}\text { Mesoporous } \\
\text { (disordered) }\end{array}$ & 238 & $\begin{array}{c}3.8 \text { (Uni- } \\
\text { modal pore) }\end{array}$ & $\begin{array}{l}\text { Hydrophilic } \\
\text { surface }\end{array}$ & 14.7 & 43.01 & 416.89 \\
\hline $\begin{array}{l}\text { Silica } \\
\left(\mathrm{SiO}_{2}\right)\end{array}$ & $\begin{array}{l}\text { Mesoporous } \\
\text { (disordered) }\end{array}$ & 550 & $\begin{array}{c}4.9 \text { (Uni } \\
\text { modal pore) }\end{array}$ & $\begin{array}{l}\text { Hydrophilic } \\
\text { surface }\end{array}$ & 8.70 & 29.5 & 243.78 \\
\hline $\begin{array}{l}\text { Montmorillo } \\
\text { nite K-10 }\end{array}$ & Mesoporous & 242 & $\begin{array}{c}6.5 \text { (Uni- } \\
\text { modal pore) }\end{array}$ & $\begin{array}{l}\text { Hydrophilic } \\
\text { surface }\end{array}$ & 18.6 & 52.8 & 498.78 \\
\hline $\begin{array}{l}\text { ALS-WO } \\
\text { PG aerogel }\end{array}$ & \multirow{5}{*}{$\begin{array}{c}\text { Hierarchically } \\
\text { porous } \\
\text { (large \& small } \\
\text { mesoporous, } \\
\text { macroporous) }\end{array}$} & 329 & $\begin{array}{c}5.5,12.1 \\
\text { (Bimodal } \\
\text { pore) }\end{array}$ & $\begin{array}{c}\text { Hydrophilic } \\
\text { surface }\end{array}$ & 11.2 & 41.40 & 135.86 \\
\hline $\begin{array}{l}\text { ALS-PG } \\
\text { aerogel }\end{array}$ & & 497 & $\begin{array}{c}\text { 3.9, 8.7, 26.6 } \\
\text { (Tri-modal } \\
\text { pore) }\end{array}$ & $\begin{array}{c}\text { Hydrophilic } \\
\text { surface }\end{array}$ & 32.3 & 74.21 & 728.75 \\
\hline $\begin{array}{l}\text { MTMS@A } \\
\text { LS-PG } \\
\text { aerogel }\end{array}$ & & 341 & $\begin{array}{c}4.0,8.7,15.7 \\
\text { (Tri-modal } \\
\text { pore) }\end{array}$ & $\begin{array}{c}\text { Hydrophobic } \\
\text { surface }\end{array}$ & 69.8 & 96.87 & 971.72 \\
\hline $\begin{array}{l}\text { APTMS@ } \\
\text { ALS-PG } \\
\text { aerogel }\end{array}$ & & 298 & $\begin{array}{c}\text { 3.6, 8.6,19.6 } \\
\text { (Tri-modal } \\
\text { pore) }\end{array}$ & $\begin{array}{c}\text { Positively } \\
\text { charged } \\
\text { surface }\end{array}$ & 65.1 & 94.96 & 967.26 \\
\hline $\begin{array}{l}\text { GA@APT } \\
\text { MS@ALS- } \\
\text { PG aerogel }\end{array}$ & & 224 & $\begin{array}{c}\text { 3.6, 8.5, 19.4 } \\
\text { (Tri-modal } \\
\text { pore) }\end{array}$ & $\begin{array}{c}\text { Hydrophilic } \\
\text { surface }\end{array}$ & 34.2 & 74.42 & 701.96 \\
\hline $\begin{array}{l}\text { a Polymeric } \\
\text { Cellulose } \\
\text { micro-beads }\end{array}$ & $\begin{array}{l}\text { Mesoporous } \\
\text { (disordered) }\end{array}$ & 211 & $\begin{array}{l}4.8 \\
-\end{array}$ & $\begin{array}{l}\text { Hydrophilic } \\
\text { surface }\end{array}$ & 12.7 & 40.7 & 398.78 \\
\hline $\begin{array}{l}\text { Amberlite } \\
\text { XAD-2 } \\
\text { Resin }\end{array}$ & $\begin{array}{l}\text { Mesoporous } \\
\text { (disordered) }\end{array}$ & 300 & $\begin{array}{l}9 \\
-\end{array}$ & $\begin{array}{l}\text { Positively } \\
\text { charged } \\
\text { surface }\end{array}$ & 71.2 & 98.6 & 989.51 \\
\hline
\end{tabular}

a prepared using carboxymethyl cellulose via ionotropic gelation method.

The performance of different standard supports for the immobilization of steapsin lipase is shown in Table S5. Zeolites showed poor protein loading and immobilization efficiency when compared to all the tested supports, probably due to the serious diffusion limitation owing to their small pore diameter in micropore domain. Improvement in loading capacity was observed when a series of mesoporous supports (alumina, silica, MCM-41 and montmorillonite K-10) was used. However, with the use of hierarchically porous aerogel support we could achieve still higher loading and immobilization efficiency. This clearly supports the beneficial effect of multidimensional porosity in 


\begin{abstract}
ALS-PG that enhanced the inclusion of large biomolecules (enzyme loading) and immobilization rates due to the effective transport of substrate and product in the pore matrix. In addition to the pore characteristics, surface properties of the support also found to strongly influence the immobilization efficiency, which is clearly seen in the results of surface functionalized supports. Moreover, the polymeric ionic exchange resin with highly positively charged surface characteristics led to better immobilization, in spite of its lower specific area and porosity compared to other tested materials.
\end{abstract}

\title{
$\underline{\text { 5. Supporting Information References }}$
}

(1) Xia, Y.; Zhang, W.; Xiao, Z.; Huang, H.; Zeng, H.; Chen, X.; Chen, F.; Gan, Y.; Tao, X. Biotemplated fabrication of hierarchically porous $\mathrm{NiO} / \mathrm{C}$ composite from lotus pollen grains for lithium-ion batteries. J. Mater. Chem. 2012, 22, 9209-9215.

(2) Knothe, G. Analytical methods used in the production and fuel quality assessment of biodiesel. Trans. ASAE. 2001, 44, 193.

(3) Sankaranarayanan, S.; Churchil, A. A.; Kannan, S. Transesterification of edible, non-edible and used cooking oils for biodiesel production using calcined layered double hydroxides as reusable base catalysts. Bioresour. Technol. 2012, 109, 57-62.

(4) Mutreja,V.; Singh, S.; Ali, A. Biodiesel from mutton fat using $\mathrm{KOH}$ impregnated $\mathrm{MgO}$ as heterogeneous catalysts. Renewable Energy 2011, 36, 2253-2258

(5) Patel H.; Patel R.; Patel G. Ionotropic Gelation Technique For Microencapsulation Of Antihypertensive Drug. Webmed Central Pharmaceutical Sciences 2010; 10, WMC00922. 